\title{
Features and use of glass-ceramics in fabrication of fixed prosthetic restorations
}

\section{Właściwości i zastosowanie ceramiki szklanej w wykonawstwie stałych uzupelnień protetycznych}

\section{Joanna Maria Gadomska, Anna Kochanek-Leśniewska}

Katedra Protetyki Stomatologicznej, Warszawski Uniwersytet Medyczny

Department of Prosthodontics, Medical University of Warsaw

Kierownik: prof. dr hab. n. med. Elżbieta Mierzwińska-Nastalska

KEY WORDS:

dental ceramics, all-ceramic fixed restorations, glass ceramics, leucite ceramics, lithium disilicate ceramics

\section{Summary}

Due to the rapid development of materials science and production technologies in dentistry, especially computer-aided techniques in recent years, the range of indications to apply fullceramic fixed restorations not only in the anterior segment of the dental arch but also in the premolar and molar region has considerably widened. Because patient's expectations relating to the aesthetics of their dentition are constantly on the increase, more and more commonly fullceramic replacements become the first-choice of treatment for interdental gaps restoration and reconstruction of the dental hard tissues deficiencies. Among the types of ceramics known and currently used in manufacturing fixed restorations, glass-ceramics is used more and more often, as it is characterized by both high aesthetics and satisfactory parameters of mechanical strength.

The aim of this publication is to systematize and compare the most commonly used types of glass-ceramics to produce full-ceramic fixed restorations. Their advantages and disadvantages and indications and contraindications to their application in various clinical cases have also been discussed.
HASŁA INDEKSOWE:

ceramika dentystyczna, uzupełnienia stałe całoceramiczne, ceramika szklana, ceramika leucytowa, ceramika dwukrzemowo-litowa

\section{Streszczenie}

Niezwykle dynamiczny rozwój $w$ dziedzinie materiałoznawstwa stomatologicznego oraz technologii wytwarzania, ze szczególnym uwzględnieniem technik komputerowych, na przestrzeni ostatnich lat znacznie rozszerzyt zakres wskazań do stosowania catoceramicznych statych uzupetnień protetycznych, nie tylko $w$ przednim odcinku tuku zębowego ale także $w$ obrębie zębów trzonowych i przedtrzonowych. Nieustannie wzrastajace wymagania pacjentów dotyczace estetyki uzębienia sprawity, iż coraz powszechniej leczeniem z wyboru jest uzupetnianie braków międzyzębowych oraz odtwarzanie jakościowych ubytków tkanek twardych zębów z zastosowaniem konstrukcji całoceramicznych. Wśród znanych $i$ wykorzystywanych obecnie $w$ produkcji statych uzupetnień protetycznych rodzajów ceramiki coraz szerzej stosowana jest ceramika szklana, gdyż cechuje się zarówno bardzo wysokimi walorami estetycznymi, jak również zadowalajacymi parametrami wytrzymatości mechanicznej.

Celem niniejszej pracy jest usystematyzowanie i porównanie najpowszechniej obecnie stosowanych $w$ protetyce stomatologicznej wybranych rodzajów ceramik szklanych stosowanych do wykonywania stałych uzupetnień całoceramicznych, 
z jednoczesnym przedstawieniem zalet $i$ wad poszczególnych typów porcelany a także wskazań $i$ przeciwwskazań do ich zastosowania $w$ danych warunkach klinicznych.

\section{Introduction}

Attempts to use ceramic materials in dentistry were made as early as the eighteenth century, however, for widespread use they were introduced in the 1950s when Abraham Weinstein developed the technique of firing porcelain on a metal frame. The unquestionable advantage of fixed metal-ceramic restorations is high resistance to cracks and fractures, even under the influence of significant occlusal loads released in the lateral segments of the dental arch. However, there are numerous disadvantages to crowns and metal-ceramic bridges, among which the most frequently mentioned are: unsatisfactory aesthetic effect associated with a lack of translucency, frequently observed gray discoloration and recession of the marginal gum and visible margin of restoration. In addition, insufficient biocompatibility, as well as the risk of allergic reactions and electrogalvanic phenomena in the oral environment, have become an incentive to look for technologies that would allow the elimination of metal from permanent prosthetic constructions. ${ }^{1,2}$

All-ceramic restorations are characterized by biocompatibility and very good aesthetics. High translucency and colour stability enable faithful reproduction of the patient's natural dentition. The smooth surface of porcelain, which is not susceptible to tarnishing, reduces the accumulation of bacterial plaque, and ensures healthy marginal periodontium. The low coefficient of thermal conductivity of ceramic materials and the possibility of their adhesive cementation clearly reduce

\section{Wstęp}

Próby wykorzystania materiałów ceramicznych w stomatologii podejmowano już w XVIII w., jednak do powszechnego użycia zostały wprowadzone dopiero w latach 50-tych XX w., kiedy to Abraham Weinstein opracował technikę napalania porcelany na podbudowę metalową. Niewątpliwą zaletą stałych uzupełnień metalowo-ceramicznych jest duża odporność na pęknięcia i złamania, nawet pod wpływem znacznych obciążeń zgryzowych wyzwalanych w strefach bocznych łuku zębowego. Istnieją jednak liczne wady koron i mostów metalowo-ceramicznych, wśród których najczęściej wymieniane to: niezadowalający efekt estetyczny związany z brakiem przezierności, obserwowane nierzadko szare przebarwienia, recesja dziąsła brzeżnego i widoczny brzeg uzupełnienia. Dodatkowo niedostateczna biozgodność, a także ryzyko wystąpienia reakcji alergicznych i zjawisk elektrogalwanicznych w środowisku jamy ustnej, stały się bodźcem do poszukiwania technologii, które umożliwiłyby wyeliminowanie metalu ze stałych konstrukcji protetycznych. ${ }^{1,2}$

Uzupełnienia całoceramiczne charakteryzują się biokompatybilnością i bardzo dobrą estetyką. Duża przezierność i stabilność koloru umożliwiają wierne odtworzenie naturalnego uzębienia pacjenta. Gładka, niepodlegająca zmatowieniu powierzchnia porcelany ogranicza akumulację płytki bakteryjnej, umożliwiając zachowanie zdrowego przyzębia brzeżnego. Niski współczynnik przewodnictwa cieplnego materiałów ceramicznych i możliwość ich adhezyjnego cementowania wyraźnie 


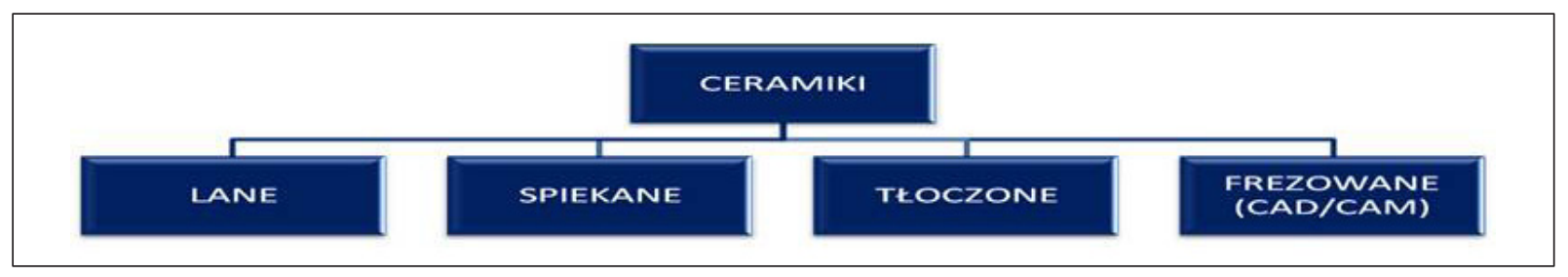

Fig. 1. Classification of ceramics acc. to processing technology.

Ryc. 1. Podziat ceramik ze względu na technologie przetwarzania.

the risk of post-operative hypersensitivity of abutment teeth with vital pulp. In addition, the proper adhesion of ceramic material to hard dental tissues has a positive effect on the strength of the structure of the restoration. ${ }^{1-7}$ Due to insufficient mechanical strength and brittleness predisposing to fractures and cracks, the indications for the use of allceramic restorations were initially limited to single crowns and veneers as well as short bridges in the anterior segment of the dental arch. Significant technological progress and the development of dental materials science, which has taken place over the last three decades, made it possible to extend durable, allceramic constructions to the molar region. ${ }^{8-10}$

Ceramics are divided according to the processing technology: sintered, cast, pressed, and milled in CAD-CAM technology (Fig. 1). However, it seems more reasonable to classify the types of dental porcelain in terms of their chemical composition, since the microstructure and phase composition determine different physical properties, and thus indications and possibilities of use in given clinical conditions. The division taking into account the structure of ceramics includes the following groups: glass-ceramics (feldspar ceramics based on aluminum silicate - field spatula, leucite ceramics based on potassium aluminosilicate, lithium disilicate ceramics based on lithium disilicate, glass-ceramics based on tetra silicon fluoroamine-mica) and oxide ceramics (ceramics based on alumina (III), ceramics based on zirconia). Each group zmniejszają ryzyko wystąpienia nadwrażliwości pozabiegowej zębów filarowych z żywą miazgą. Ponadto adhezyjne połączenie materiału ceramicznego z twardymi tkankami zęba korzystnie wpływa na wytrzymałość konstrukcji protetycznej. ${ }^{1-7}$ Ze względu na niedostateczną wytrzymałość mechaniczną i kruchość predysponującą do złamań i pęknięć, początkowo wskazania do stosowania uzupełnień całoceramicznych ograniczały się jedynie do pojedynczych koron i licówek oraz krótkich mostów w przednim odcinku łuku zębowego. Znaczny postęp technologiczny i rozwój materiałoznawstwa stomatologicznego, który dokonał się na przestrzeni ostatnich trzech dekad pozwolił na wykonywanie rozległych, wytrzymałych konstrukcji całoceramicznych również w obrębie zębów trzonowych. ${ }^{8-10}$

Ze względu na technologię przetwarzania wyróżnia się ceramiki: spiekane, lane, tłoczone oraz frezowane w technologii CAD/CAM (ryc. 1). Jednak bardziej zasadne wydaje się sklasyfikowanie rodzajów porcelany dentystycznej pod względem składu chemicznego, gdyż mikrostruktura i skład fazowy warunkują różne właściwości fizyczne, a tym samym wskazania i możliwości zastosowania $\mathrm{w}$ danych warunkach klinicznych. Podział uwzględniający strukturę ceramiki obejmuje następujące grupy: ceramiki szklane (ceramika skaleniowa na bazie krzemianu glinu - szpat polny, ceramika leucytowa na bazie glinokrzemianu potasu, ceramika dwukrzemowo-litowa na bazie dwukrzemianu litu, ceramika szklana na bazie fluoroaminy czterokrzemowej - mika) 


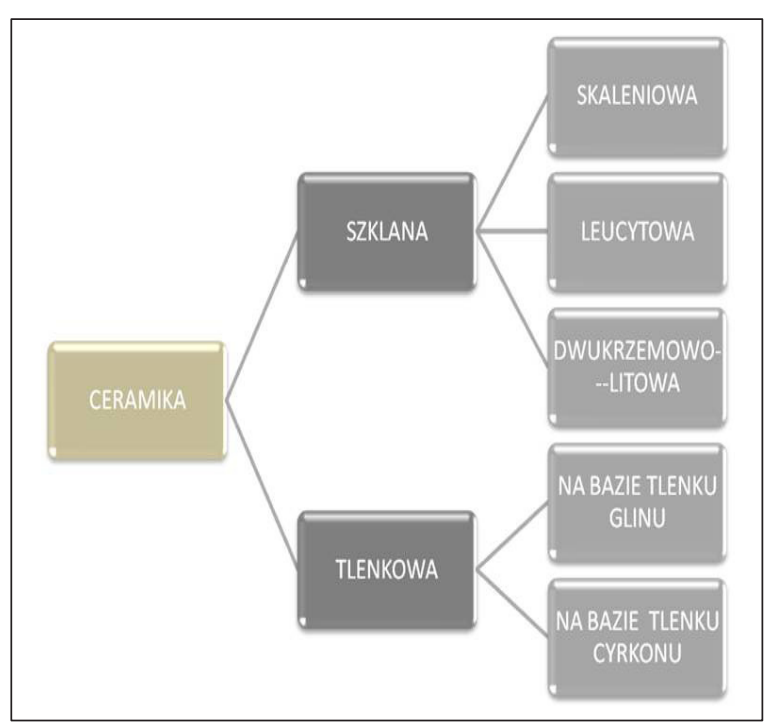

Fig. 2. Classification of ceramics acc. to its structure. Ryc. 2. Podział ceramik uwzględniajacy jej strukturę.

is assigned specific mechanical and optical properties (Fig. 2).

\section{Feldspar ceramics}

Feldspar ceramics (field ceramics, field spatula, dental porcelain) is the oldest ceramic material currently used in manufacturing fixed prosthetic restorations. The heterogeneous structure of this material consists of quartz crystals $\left(\mathrm{SiO}_{2}\right.$, potassium aluminum silicate $\left(\mathrm{K}_{2} \mathrm{O} \cdot \mathrm{Al}_{2} \mathrm{O}_{3} \cdot 6 \mathrm{SiO}_{2}\right)$ and alumina $\left(\mathrm{Al}_{2} \mathrm{O}_{3}\right)$ dispersed in the amorphous mass of silica. Feldspar ceramics is characterized by satisfactory aesthetics, enabling faithful reconstruction of lost tooth tissues. However, due to the very low mechanical strength (60-110 MPa) and high brittleness, its use in the manufacture of all-ceramic permanent prosthetic restorations is limited to veneers with a minimally invasive preparation of the abutment tooth, and to crown inlays. Currently, dental porcelain is mainly used for facing metal and ceramic substructures of fixed prosthetic constructions. ${ }^{1,3}$ The materials used in the manufacture of all-ceramic restorations oraz ceramiki tlenkowe (ceramika na bazie tlenku glinu (III), ceramika na bazie dwutlenku cyrkonu). Każdej grupie przypisuje się określone właściwości mechaniczne oraz optyczne (ryc. 2).

\section{Ceramika skaleniowa}

Ceramika skaleniowa (ceramika feldszpatowa, szpat polny, porcelana dentystyczna) jest najstarszym spośród materiałów ceramicznych stosowanych obecnie do wykonywania stałych uzupełnień protetycznych. Niejednorodna struktura tego tworzywa składa się z kryształów kwarcu $\left(\mathrm{SiO}_{2}\right.$, krzemianu glinowo-potasowego $\left(\mathrm{K}_{2} \mathrm{O} \cdot \mathrm{Al}_{2} \mathrm{O}_{3} \cdot 6 \mathrm{SiO}_{2}\right)$ oraz tlenku glinu $\left(\mathrm{Al}_{2} \mathrm{O}_{3}\right)$, rozproszonych $\mathrm{w}$ amorficznej masie krzemionki. Ceramika skaleniowa charakteryzuje się zadowalającą estetyką, umożliwiając wierne odtworzenie utraconych tkanek zęba. Jednak ze względu na bardzo małą wytrzymałość mechaniczną (60-110 MPa) i dużą kruchość, jej zastosowanie w wykonawstwie całoceramicznych stałych uzupełnień protetycznych ograniczone jest do licówek z minimalnie inwazyjną preparacją filaru oraz wkładów koronowych. Obecnie porcelana dentystyczna wykorzystywana jest przede wszystkim do licowania podbudowy metalowej i ceramicznej stałych konstrukcji protetycznych. ${ }^{1,3}$ Materiały stosowane w wykonawstwie uzupełnień całoceramicznych charakteryzuje zwiększona zawartość komponenty krystalicznej (35-99\%), co znacznie poprawia parametry wytrzymałości mechanicznej. ${ }^{3,11}$

\section{Ceramika leucytowa}

Ceramika leucytowa jest zmodyfikowaną porcelaną skaleniową. Inkorporacja tetragonalnych kryształów leucytu o wymiarach 1-5 $\mu \mathrm{m}$ w szklaną matrycę pozwoliła na zwiększenie wytrzymałości konstrukcji protetycznych. Wytrzymałość na zginanie rzędu $135 \mathrm{MPa}$ rozszerzyła zakres wskazań do stosowania ceramiki leucytowej. Poza licowaniem 
are characterized by an increased content of crystalline components (35-99\%), which significantly improves the parameters of mechanical strength. ${ }^{3,11}$

\section{Leucite ceramics}

Leucite ceramics is the modified feldspar porcelain. Incorporation of tetragonal leucite crystals with dimensions of $1-5 \mu \mathrm{m}$ into a glass matrix allowed increasing the strength of prosthetic constructions. The flexural strength of $135 \mathrm{MPa}$ expanded the range of indications for the use of leucite ceramics. In addition to veneering metal and ceramic substructures made of zirconia or aluminum oxide, it is also used to make veneers, inlays, and single crowns. ${ }^{2,11}$ The fracture toughness expressed as a stress intensity factor is about $1.3 \mathrm{MPa} / \mathrm{m}^{1 / 2}$, while the hardness of glass-ceramics reinforced with leucite crystals reaches the value of 6.5 GPa on the Vickers scale. A significant content of the glassy phase determines the susceptibility of leucite ceramics to etching with hydrofluoric acid. ${ }^{12}$ The formation of pores in the structure of a ceramic material allows obtaining a micromechanical connection with the adhesive system and composite cement, thereby increasing the resistance of the inserted restoration to cracking. ${ }^{4}$ Clinical research has shown that long-term therapeutic success and long-term survival in the oral cavity of fullcontour ceramic restorations reinforced with leucite crystals are closely related to minimally invasive abutment tooth preparation, which allows their adhesive cementation to natural enamel. ${ }^{9,12}$

Undoubtedly, one of the biggest advantages of constructions made of leucite ceramics is their very good aesthetics. The relatively small proportion of the crystalline phase (about $20 \%$ ) and the refractive index almost identical for leucite $(\mathrm{n}=1.51)$ and the surrounding glassy phase $(n=1.52-1.53)$ make for better translucency. ${ }^{9,12}$ Thin, highly transparent podbudowy metalowej i ceramicznej uzupełnień z dwutlenku cyrkonu lub tlenku glinu, stosowana jest również do wykonywania licówek, wkładów koronowych oraz pojedynczych koron. ${ }^{2,11}$ Odporność na kruche pękanie wyrażona współczynnikiem intensywności naprężeń wynosi około $1,3 \mathrm{MPa} / \mathrm{m}^{1 / 2}$, zaś twardość ceramiki szklanej wzmacnianej kryształami leucytu osiąga wartość 6,5 GPa w skali Vickersa. Znaczny udział fazy szklistej warunkuje podatność ceramiki leucytowej na wytrawianie kwasem fluorowodorowym. ${ }^{12}$ Wytworzenie porów w strukturze materiału ceramicznego umożliwia uzyskanie mikromechanicznego połączenia z systemem adhezyjnym i cementem kompozytowym, zwiększając tym samym odporność osadzonego uzupełnienia na pękanie. ${ }^{4}$ Prowadzone badania kliniczne dowiodły, iż długoterminowy sukces terapeutyczny i wieloletnie przetrwanie w jamie ustnej pełnokonturowych uzupełnień ceramicznych wzmacnianych kryształami leucytu jest ściśle związane z minimalnie inwazyjną preparacją filaru, która umożliwia ich adhezyjne cementowanie do naturalnego szkliwa. ${ }^{9,12}$

Niewątpliwie jedną z największych zalet konstrukcji wykonanych z ceramiki leucytowej jest ich bardzo dobra estetyka. Stosunkowo niewielki udział fazy krystalicznej (około 20\%) oraz wartość współczynnika załamania światła niemalże jednakowa dla leucytu $(\mathrm{n}=1,51)$ i otaczającej go fazy szklistej $(n=1,52-1,53)$ stanowią o lepszej przezierności uzupełnień. ${ }^{9,12}$ Cienkie, wysoce transparentne korony i licówki $\mathrm{z}$ ceramiki leucytowej zalecane są do odbudowy nieprzebarwionych zębów z żywą miazgą. Wraz ze wzrostem grubości ścian uzupełnienia wzrasta jego opakerowość, dlatego w celu zamaskowania przebarwienia filaru wymagana jest bardziej radykalna preparacja. Istotne znaczenie ma również dobór cementu o właściwej przezierności, by zapobiec zmianie barwy osadzanego uzupełnienia. ${ }^{1}$

Powszechnie obecnie stosowanym systemem 
crowns and veneers made of leucite ceramics are recommended for the reconstruction of non-discolored teeth with vital pulp. As the thickness of the walls of the restoration increases, its opacity also increases; therefore, more radical preparation is required to mask the discoloration of the abutment tooth. The selection of cement with appropriate translucency is also important to prevent any change of the colour of the restoration. ${ }^{1}$

IPS Empress (Ivoclar Vivadent, Liechtenstein) is a commonly used leucitereinforced glass-ceramic system. This material consists of $63 \%$ silicon dioxide, $19 \%$ alumina (III) and about 20\% leucite crystals, and belongs to the group of pressed ceramics. In the manufacturing process, the substructure of the restoration is initially modeled from foundry wax and then embedded in refractory mass. Production technology based on the injection of a thermally plasticized ceramic block into the mold formed after complete wax burning eliminates shrinkage and significantly reduces porosity, which has a positive effect on the mechanical strength of the restorations. The pressed restoration is then subjected to characterization. Characterization with the technique of painting (staining) consists in surface staining of full-contour restoration with paints, while in layered technique the individual features of the tooth anatomy are given by facing the embossed substructure with feldspar porcelain. The most satisfactory aesthetic effect can be obtained in the cut-back technique. The embossed restoration is reduced in the incisal area. The application of special layers of feldspar ceramics in this area ensures translucency, opalescence, and fluorescence as close as possible to those of enamel and dentine of natural teeth. Improvement of aesthetic values and increase of mechanical strength were achieved in the Empress Esthetic Line system (Ivoclar Vivadent, Liechtenstein), which uses glass-ceramics reinforced with ceramiki szklanej wzmacnianej leucytem jest IPS Empress (Ivoclar Vivadent, Lichtenstein). Materiał ten składa się w $63 \%$ z dwutlenku krzemu, 19\% z tlenku glinu (III) oraz w około $20 \%$ z kryształów leucytu i należy do grupy ceramik tłoczonych (prasowanych). W procesie wytwarzania podbudowa uzupełnienia wstępnie modelowana jest $\mathrm{z}$ wosku odlewniczego, a następnie zatapiana w masie ogniotrwałej. Technologia produkcji oparta na wtłaczaniu uplastycznionego termicznie bloczka materiału ceramicznego do formy powstałej po całkowitym wypaleniu wosku eliminuje skurcz i znacznie zmniejsza porowatość, co korzystnie wpływa na wytrzymałość mechaniczną uzupełnień. Wytłoczone uzupełnienie poddawane jest następnie charakteryzacji. Charakteryzacja techniką malowania (staining) polega na powierzchniowym barwieniu pełnokonturowego uzupełnienia farbami do porcelany, zaś $\mathrm{w}$ technice warstwowej indywidualne cechy anatomii zęba nadawane są poprzez licowanie wytłoczonej podbudowy porcelaną skaleniową. Najbardziej zadowalający efekt estetyczny można uzyskać w technice cut-back. Wytłoczone uzupełnienie redukowane jest w rejonie brzegu siecznego. Aplikacja specjalnych warstw ceramiki skaleniowej w tym obszarze zapewnia przezierność, opalescencję i fluorescencję maksymalnie zbliżone do tych, jakie wykazują szkliwo i zębina zębów naturalnych. Poprawę walorów estetycznych oraz zwiększenie wytrzymałości mechanicznej osiągnięto w systemie Empress Esthetic Line (Ivoclar Vivadent, Lichtenstein), który wykorzystuje ceramikę szklaną wzmacnianą kryształami leucytu o mniejszych wymiarach, które są gęściej upakowane w matrycy szklanej. Rozwój technik komputerowych pozwolił na zastosowanie ceramiki leucytowej w technologii CAD/CAM. W systemie IPS Empress CAD na podstawie wycisku wirtualnego pobieranego za pomocą skanera wewnątrzustnego, uzupełnienie wycinane jest z bloczka ceramiki leucytowej, a następnie 
leucite crystals of smaller dimensions that are more densely packed in a glass matrix. The development of computer techniques has enabled using the leucite ceramics in CADCAM technology. In the IPS Empress CAD system, based on a virtual impression taken with an intraoral scanner, the restoration is cut from a leucite ceramic block, and then subjected to characterization with the use of special paints for porcelain and then glazed. Structures made of relatively soft leucite ceramics are milled in crystallized form as full-contour restorations in the final size and colour. The cut-out restoration does not require firing in the kiln, but only polishing with the use of a composite eraser and paste just before settling in the mouth. Thanks to the simple and short-lasting processing technology, now leucite ceramics are more and more often used in the single-visit treatment regimen. Blocks with three levels of translucency are available: HT - high, LT - low, and MultiBlocks lower translucency in the dentine area and higher in the incisal region (Ivoclar Vivadent, Liechtenstein). Inlays, crowns and veneers made of leucite ceramics in CADCAM technology are characterized by very good marginal tightness and satisfactory aesthetics. ${ }^{1,2}$

\section{Lithium disilicate porcelain}

In modern dental prosthetics, the most commonly used type of glass-ceramics is lithium disilicate. The compact structure of small $(0.5-4.0 \mu \mathrm{m})$, prismatic lithium disilicate crystals, constituting about $70 \%$ of the material volume, surrounded by a glass matrix, determines high mechanical strength. More than twice as much resistance to brittle cracking (2.9 $\mathrm{MPa} \mathrm{x} \mathrm{m}^{1 / 2}$ ) compared to leucite ceramics, and high bending strength (400 $\mathrm{MPa}$ ), three times higher compared to leucite ceramics and up to five times compared to feldspar ceramics significantly expanded the poddawane charakteryzacji farbami do porcelany i glazurowaniu. Konstrukcje ze stosunkowo miękkiej ceramiki leucytowej frezowane są w postaci krystalizowanej jako uzupełnienia pełnokonturowe w docelowym wymiarze i kolorze. Wycięte uzupełnienie nie wymaga wypalania $\mathrm{w}$ piecu, a jedynie polerowania $\mathrm{z}$ zastosowaniem gumki do kompozytu i pasty bezpośrednio przed osadzeniem $\mathrm{w}$ jamie ustnej. Dzięki nieskomplikowanej i krótkotrwałej technologii przetwarzania, obecnie coraz częściej ceramika leucytowa wykorzystywana jest w schemacie leczenia jednowizytowego. Dostępne są bloczki o trzech poziomach przezierności: HT - wysokiej, LT - niskiej i MultiBlocks - niższej w części zębinowej i wyższej w rejonie brzegu siecznego (Ivoclar Vivadent, Lichtenstein). Wkłady koronowe, korony oraz licówki wykonane z ceramiki leucytowej w technologii CAD/CAM charakteryzują się bardzo dobrą szczelnością brzeżną oraz zadowalającą estetyką. ${ }^{1,2}$

\section{Ceramika dwukrzemowo-litowa}

We współczesnej protetyce stomatologicznej najpowszechniej stosowanym rodzajem ceramiki szklanej jest ceramika dwukrzemowo-litowa. Zwarta struktura małych (0,5-4,0 $\mu \mathrm{m})$, pryzmatycznych kryształów dwukrzemianu litu, stanowiących około $70 \%$ objętości materiału, otoczonych szklaną matrycą decyduje o wysokiej wytrzymałości mechanicznej. Ponad dwukrotnie większa odporność na kruche pękanie $\left(2,9 \mathrm{MPa} \times \mathrm{m}^{1 / 2}\right)$ w stosunku do ceramiki leucytowej oraz duża wytrzymałość na zginanie (400 MPa), trzykrotnie wyższa w porównaniu do ceramiki leucytowej i aż pięciokrotnie względem ceramiki skaleniowej, znacznie rozszerzyły zakres wskazań do stosowania. 2,4,9,12-14 Ceramika dwukrzemowo-litowa wykazuje ścieralność zbliżoną do naturalnego szkliwa, nie powodując tym samym nadmiernego starcia zębów w łuku przeciwstawnym. ${ }^{2,15} \mathrm{Z}$ ceramiki szklanej wzmacnianej 
range of indications for use. ${ }^{2,4,9,12-14}$ Lithium disilicate exhibits abrasion similar to natural enamel, thus not causing excessive tooth wear in the opposing arch. ${ }^{2,15}$ Veneers of thickness of at least $0.3 \mathrm{~mm}$ are made from the ceramics reinforced with lithium silicate.

Lithium disilicate porcelain is also widely used in making inlays, crowns, telescopic crowns, implant-supported hybrid crowns, as well as three-unit bridges that may include a second premolar as a distal abutment, on condition that the span in area of the first premolar does not exceed $7.0-8.0 \mathrm{~mm}$ in the vestibule-lingual plane, which corresponds to the natural width of that tooth. ${ }^{9,12,13,15}$ The recommended length of bridge spans in the anterior segment of the dental arch is $11 \mathrm{~mm}$, while in the lateral segments - a maximum of $9 \mathrm{~mm}$. The minimum crosssectional area of the connectors in the bridges, ensuring optimal resistance to cracking, should be $16 \mathrm{~mm}^{2}{ }^{2,16-19}$ Elongated lithium disilicate crystals are arranged parallel to the interacting tensile forces. It is a mechanism that additionally improves the mechanical strength, particularly important in the area of connections of the multi-component fixed restorations. In addition to structures based on own teeth, lithium disilicate is widely used in the protocol of implant-prosthetic treatment. Lithium disilicate crowns can be cemented by a dentist on standard titanium abutments screwed to the implant.

The relatively new solution is the use of hybrid crowns. A crown made of a lithium disilicate block as a monolithic structure in CAD-CAM or Press technology is mounted on a basis made of titanium, compatible with the implant system, using composite cement in the dental prosthetics laboratory. Clinical management involves screwing the finished hybrid crown to the implant and closing the screw hole with composite material. This greatly simplifies the clinical procedure and dwukrzemianem litu wykonywane są licówki o grubości co najmniej $0,3 \mathrm{~mm}$.

Ceramika dwukrzemowo-litowa jest także szeroko stosowana w wykonawstwie wkładów koronowych, koron, koron teleskopowych, koron hybrydowych opartych na implantach, a także trzyczłonowych mostów, które swym zasięgiem mogą obejmować drugi ząb przedtrzonowy jako filar dystalny z zastrzeżeniem, iż przęsło w miejscu pierwszego zęba przedtrzonowego nie powinno przekraczać 7,0-8,0 mm w płaszczyźnie przedsionkowo-językowej, co odpowiada naturalnej szerokości tego zęba. ${ }^{9}, 12,13,15$ Zalecana długość przęseł mostów w odcinku przednim wynosi $11 \mathrm{~mm}$, natomiast w bocznych strefach łuku zębowego - maksymalnie $9 \mathrm{~mm}$. Minimalna powierzchnia przekroju poprzecznego łączników w mostach, zapewniająca optymalną odporność na pękanie powinna wynosić $16 \mathrm{~mm}^{2} .^{2,16-19}$ Podłużne kryształy dwukrzemianu litu układają się równolegle do oddziałujących sił rozciągających. Jest to mechanizm, który dodatkowo poprawia wytrzymałość mechaniczną, szczególnie istotny $\mathrm{w}$ rejonie połączeń wieloczłonowych uzupełnień stałych. Poza konstrukcjami osadzanymi na zębach własnych, dwukrzemian litu znajduje szerokie zastosowanie w protokole leczenia implantoprotetycznego. Korony z dwukrzemianu litu mogą być cementowane przez lekarza na łącznikach standardowych tytanowych przykręcanych do implantu.

Stosunkowo nowym rozwiązaniem jest zastosowanie koron hybrydowych. Korona wytworzona z bloku dwukrzemianu litu jako monolityczna struktura w technologii CAD/CAM lub Press osadzana jest na bazie tytanowej kompatybilnej $\mathrm{z}$ systemem implantologicznym, z wykorzystaniem cementu kompozytowego w laboratorium protetyki stomatologicznej. Postępowanie kliniczne obejmuje przykręcenie gotowej korony hybrydowej do implantu i zamknięcie otworu dla śruby materiałem kompozytowym. Znacznie upraszcza to procedurę 
minimizes the risk of doctor's error during cementation. The excellent aesthetics of lithium disilicate restorations which are supported on implants, their satisfactory mechanical strength parameters and adaptive abrasion similar to those of natural enamel restore the continuity of the dental arch both in the anterior and lateral segment in a way that most faithfully reproduces physiological conditions. . $^{1,16-18,20}$

Studies carried out by Guess et al. $(2010)^{21}$ and Kim et al. (2003) 22 showed less susceptibility to damage to monolithic lithium disilicate crowns compared to crowns on the zirconium substructure, among which chipping of veneering porcelain and crack in its area were often observed. ${ }^{10}$

Despite the significant content of the crystalline phase, constructions made of lithium disilicate are characterized by transparency similar to that of the hard tissues of the tooth, because the refractive index of lithium disilicate crystals is comparable to the refractive index of healthy enamel $(n=1.62)$. Good transparency allows manufacturing highly aesthetic full-contour restorations that blend very well with the patient's natural dentition. 4,10,12,14,15,20

Chemical properties are determined by the presence of a glass matrix, which is why, like leucite ceramics, lithium disilicate ceramics are susceptible to etching only with hydrofluoric acid, while types of adhesive cements with a properly selected colour are dedicated to the placement of the restoration. Creating a chemical bond between the restoration, cement and tooth tissues increases the mechanical strength of the structure and also eliminates the risk of de-cementation of the restoration from an abutment tooth with low retentive geometry. Therefore, it is possible to rebuild low, narrow abutment teeth with converging walls, as well as minimally invasive preparation of wellpreserved teeth. ${ }^{4,12}$ kliniczną i minimalizuje ryzyko popełnienia błędu przez lekarza podczas cementowania. Doskonała estetyka uzupełnień z dwukrzemianu litu wspartych na implantach, ich zadowalające parametry wytrzymałości mechanicznej oraz ścieralność dostosowawcza zbliżona do ścieralności naturalnego szkliwa pozwalają na przywrócenie ciągłości łuku zębowego zarówno w przednim, jak i bocznym odcinku w sposób najwierniej odtwarzający warunki fizjologiczne. ${ }^{1,16-18,20}$

Badania przeprowadzone przez Guess i wsp. $(2010)^{21}$ oraz Kim i wsp. $(2003)^{22}$ wykazały mniejszą podatność na uszkodzenia monolitycznych koron z dwukrzemianu litu w porównaniu do koron na podbudowie cyrkonowej, wśród których często obserwowanymi uszkodzeniami były odpryskiwanie warstwy porcelany licującej (chipping) oraz pęknięcia w jej obszarze. ${ }^{10}$

Pomimo znacznego udziału fazy krystalicznej, konstrukcje wykonane z ceramiki dwukrzemowo litowej charakteryzują się transparencją zbliżoną do twardych tkanek zęba, ponieważ współczynnik załamania światła kryształów dwukrzemianu litu jest porównywalny ze współczynnikiem refrakcji zdrowego szkliwa $(n=1,62)$. Dobra transparencja pozwala na wykonywanie wysoce estetycznych pełnokonturowych uzupełnień, które bardzo dobrze komponują się $\mathrm{z}$ naturalnym uzębieniem pacjenta. ${ }^{4,10,12,14,15,20}$

Właściwości chemiczne determinowane są obecnością macierzy szklanej, dlatego analogicznie do ceramiki leucytowej, ceramika dwukrzemowo-litowa jest podatna na wytrawianie jedynie kwasem fluorowodorowym, zaś do osadzania uzupełnień dedykowane są cementy adhezyjne o właściwie dobranej barwie. Wytworzenie chemicznego połączenia pomiędzy uzupełnieniem, cementem oraz tkankami zęba zwiększa wytrzymałość mechaniczną konstrukcji a także eliminuje ryzyko odcementowania uzupełnienia $\mathrm{z}$ filaru o mało 
Studies carried out by Okoński et al. ${ }^{16}$ have shown that polishing lithium disilicate restorations with the use of polishing tools dedicated to the processing of ceramics together with special pastes allows obtaining a perfectly smooth surface. This is important in clinical management because it creates the opportunity to manufacture all-ceramic restorations without the need for glazing in a prosthetic laboratory, and also improves the quality of the microstructure of ceramics damaged by a diamond bur during the correction of the restoration in the occlusion. The renewed smoothness of the surface of the restoration determines the properties defined as those of the main advantages of lithium disilicate ceramics, such as limited bacterial plaque accumulation, resistance to absorption of food dyes, minimal abrasion to opposing teeth and high aesthetics. ${ }^{16-18}$

High aesthetic assessment of reconstructions made of lithium disilicate, satisfactory parameters of mechanical strength, and by far the widest range of applications among known types of glass-ceramics determine its widespread use in dental prosthetics.

\section{Summary}

Permanent restorations made of glassceramics used in modern dental prosthetics allow achieving a satisfactory aesthetic effect of reconstructed teeth, but above all allow restoring physiological conditions within the stomatognathic system. The different composition and crystal structure of each ceramic material determine the indications to its use in given conditions, as well as a strictly defined clinical management protocol including proper abutment tooth preparation, the procedure of placement of the restoration, as well as follow-up care and recommendations concerning its use given to the patient. retencyjnej geometrii. Możliwa jest zatem odbudowa niskich, wąskich filarów o zbieżnych ścianach, jak również minimalnie inwazyjna preparacja dobrze zachowanych zębów. ${ }^{4,12}$

W badaniach przeprowadzonych przez Okońskiego $i$ wsp. ${ }^{16}$ wykazano, iż polerowanie uzupełnień $\mathrm{z}$ dwukrzemianu litu z zastosowaniem narzędzi polerskich dedykowanych do obróbki ceramiki wraz ze specjalnymi pastami umożliwia uzyskanie idealnie gładkiej powierzchni. Ma to istotne znaczenie w postępowaniu klinicznym, gdyż stwarza możliwość wykonywania uzupełnień całoceramicznych bez konieczności ich glazurowania w pracowni protetycznej, a także pozwala na poprawę jakości mikrostruktury ceramiki uszkodzonej wiertłem diamentowym podczas korekty okluzyjnej zacementowanych uzupełnień. Ponowne nadanie gładkości powierzchni konstrukcji determinuje przywrócenie właściwości określanych jako jedne $\mathrm{z}$ głównych zalet ceramiki dwukrzemowo-litowej takich, jak: ograniczona akumulacja płytki bakteryjnej, odporność na absorpcję barwników z pożywienia, minimalna abrazyjność względem zębów przeciwstawnych oraz wysoka estetyka. ${ }^{16-18}$

Wysoka ocena estetyczna rekonstrukcji wykonanych z ceramiki dwukrzemowo-litowej, zadowalające parametry wytrzymałości mechanicznej oraz zdecydowanie najszerszy zakres wskazań do stosowania spośród znanych ceramik szklanych decydują o jej powszechnym zastosowaniu w protetyce stomatologicznej.

\section{Podsumowanie}

Uzupełnienia stałe z ceramiki szklanej stosowane we współczesnej protetyce stomatologicznej umożliwiają osiągnięcie zadowalającego efektu estetycznego rekonstruowanych zębów, ale przede wszystkim pozwalają na przywrócenie fizjologicznych warunków w układzie stomatognatycznym. Odmienny 
The comparison of the properties of individual ceramic materials proves that the selection of the right material at the stage of treatment planning has a significant impact on the success of a patient's prosthetic rehabilitation. skład i struktura krystaliczna poszczególnych materiałów ceramicznych determinują wskazania do ich zastosowania w danych warunkach, jak również ściśle określony protokół postępowania klinicznego obejmujący właściwą preparację filaru, procedurę osadzania uzupełnienia, a także opiekę następową i zalecenia użytkowania dla pacjenta.

Porównanie właściwości poszczególnych materiałów ceramicznych dowodzi, iż dobór właściwego tworzywa na etapie planowania leczenia ma istotny wpływ na powodzenie rehabilitacji protetycznej pacjenta.

\section{References / Piśmiennictwo}

1. Szczyrek P, Mierzwińska-Nastalska E: Uzupełnienia ceramiczne. Postępowanie kliniczne i wykonawstwo laboratoryjne. Med Tour Press International, Otwock 2011.

2. Okoński P, Lasek K, Mierzwińska-Nastalska $E$ : Kliniczne zastosowanie wybranych materiałów ceramicznych. Protet Stomatol 2012; LXII, 3: 181-189.

3. Dejak B, Kacprzak M, Suliborski B, Śmielak $B$ : Struktura i niektóre właściwości ceramik dentystycznych stosowanych w uzupełnieniach pełnoceramicznych w świetle literatury. Prot Stomatol 2006; LVI, 6: 471-477.

4. Brandt S, Winter A, Lauer HCh, Kollmar $F$, Portscher-Kim SJ, Romanos GE: IPS e.max for All-Ceramic Restorations: Clinical Survival and Success Rates of Full-Coverage Crowns and Fixed Partial Dentures. MDPI 2019; 12: 462.

5. Pietruski JK, Pietruska MD: Materiały i technologie używane we współczesnej protetyce stałych uzupełnień zębowych - wady i zalety przedstawione na podstawie przeglądu piśmiennictwa i doświadczeń własnych. Stomatol Estet 2013; 9(3): 89-99.

6. Sethi S, Kakade D, Jambhekar S, Jain V: An in vitro investigation to compare the surface roughness of auto glazed, reglazed and chair side polished surfaces of Ivoclar and Vita feldspathic porcelan. J Indian Prosthodont Soc 2013; 13(4): 478-485.

7. Abu-Obaid A, AlMawash A, Alyabis N, Alzaaqi $N$ : An in vitro evaluation of the effect of polishing on the stainability of different CAD/ CAM ceramic materials. Saudi Dent J 2020; 32: $135-141$.

8. Wydra M, Grelowska I: Materiały ceramiczne w stomatologii. Szkło i ceramika 2017; 6 .

9. Zhang Y, Kelly JR: Dental ceramics for restoration and metal-veneering. Dent Clin North Am 2017; 61(4): 797-819.

10. Hamza TA, Sherif RM: Fracture Resistance of Monolithic Glass-Ceramics Versus Bilayered Zirconia-Based Restorations. J Prosthodont 2019; 28: 259-264.

11. Porada M: Podział i zastosowanie ceramik dentystycznych w zależności od ich budowy chemicznej - na podstawie piśmiennictwa. Nowocz Tech Dentyst 2015; 1: 86-88.

12. Dejak B: Kompendium wykonywania uzupełnień protetycznych. Med Tour Press International, Warszawa 2014. 
13. Bunek S: Ceramics \& Surface Treatments. Dental Advisor 2018; 35: 3.

14. Ferruzzi F, Ferrairo BM, Piras FF, Sanches Borges AF, Rubo JH: Fatigue survival and damage modes of lithium disilicate and resin nanoceramic crowns. J Appl Oral Sci 2019; 27: e20180297.

15. Majewski S: Rekonstrukcja zębów uzupełnieniami stałymi. Wydawnictwo Fundacji Rozwoju Protetyki, Kraków 2005.

16. Okoński P, Milczarek M, Szulc M, Rudnik $D$ : Wpływ opracowania mechanicznego na strukturę powierzchni ceramiki dwukrzemowo-litowej. Protet Stomatol 2015; 65(3): 225232.

17. Owen S, Reaney D, Newsome P: Finishing and polishing porcelain surfaces chairside. International Dentistry - Australasian Edition 2010; 6: 68-73.

18. Sarikaya I, Güler AU: Effects of different polishing techniques on the surface roughness of dental porcelains. J Appl Oral Sci 2010; 18: 10-16.

19. Spiechowicz E: Protetyka stomatologiczna. Wydawnictwo Lekarskie PZWL, Warszawa 2016.

20. Güngör MB, Nemli SK, Yilmaz H, Aydin $C$ : Fracture resistance of different implant supported ceramic abutment/crown systems. Eur Oral Res 2019; 53(2): 80-87.

21. Guess PC, Zhang Y, Kim JW, Rekow ED, Thompson VP: Damage and reliability of Y-TZP after cementation surface treatment. J Dent Res 2010; 89(6): 592-596.

22. Kim JH, Miranda P, Kim DK, Lawn BR: Effect of an adhesive interlayer on the fracture of a brittle coating on a supporting substrate. J Mater Res 2003; 18(1): 222-227.

Zaakceptowano do druku: 29.07.2020 r.

Adres autorów: 02-097 Warszawa, ul. Binieckiego 6.

(C) Zarząd Główny PTS 2020. 